https:/ / doi.org/10.18485/iipe_nsail.2020.ch8

Sanja KREŠTALICA ${ }^{1}$

\title{
EVOLUCIJA SHVATANJA O SUBJEKTIVITETU POJEDINCA U MEĐUNARODNOM PRAVU
}

\begin{abstract}
Apstrakt: U ovom radu polazimo od pretpostavke da je subjektivitet dinamičan koncept, podložan promjenama koje su uslovljene kontinuiranim razvojem pravila međunarodnog prava, što u konačnom utiče i na razumijevanje položaja pojedinca $u$ koordinatama pomenutog sistema. U zavisnosti od toga kako pojedini autori doživljavaju subjektivitet, kao statičnu ili dinamičnu kategoriju, čvrst standard ili rastegljiv pojam, kao suštinsko prethodno pitanje ili naknadnu potvrdu, možemo da ocijenimo i njihovo razumijevanje položaja pojedinca. Ideja prema kojoj je pojedinac subjekt međunarodnog prava nije nova, kao što nije nova ni trenutno aktuelna tendencija humanizacije pravnog poretka. Bez obzira na piščev doživljaj subjektiviteta, nesumnjivo je utvrđeno da različiti entiteti mogu biti shvaćeni kao subjekti međunarodnog prava. Određenje statusa pojedinca $\mathrm{u}$ međunarodnom pravu mijenjalo se $\mathrm{s}$ promjenom shvatanja o državi i njenoj ulozi. Za one autore koji subjektivitet smatraju osnovnom kategorijom, uslovljenom elementima koji u biću jednog entiteta treba da budu zastupljeni kumulativno, za njih je jedini subjekt država. Za one druge pak koji subjektivitet vide kao a posteriori pravnu konstrukciju, uslovljenu razvojem pravila međunarodnog prava, subjektivitet se inter alia proteže i na pojedinca. Pokazaćemo da su dileme, koje su zaokupljale klasike međunarodnog prava, u pogledu eventualnog subjektiviteta pojedinca, jednako aktuelne i danas. Cilj nam je dokazati da
\end{abstract}

\footnotetext{
${ }^{1}$ Pravni fakultet Univerziteta u Istočnom Sarajevu, sanja.tepavcevic@pravni.ues.rs.ba

Ovaj rad proističe iz opsežnog istraživanja koje je autorka sprovela prilikom izrade doktorske disertacije na temu "Položaj pojedinca u međunarodnom pravu“, odbranjene na Pravnom fakultetu Univerziteta u Beogradu 24.10.2019. godine.
} 
se u konkretnom slučaju prije radi o recepciji starih ideja i njihovom odijevanju u novo ruho, negoli o revolucionarnim novinama današnjice.

Ključne riječi: pojedinac, međunarodnopravni subjektivitet, država, nedržavni akteri.

\section{UVOD}

Pitanje statusa ili položaja pojedinca u međunarodnom pravu mijenjalo se promjenom shvatanja o državi i njenoj ulozi. U evrocentrističkom društvu klasičnog doba pojedine države su bile dominantni akteri međunarodnih odnosa, a time jedini i privilegovani subjekti međunarodnog prava. Pojedinac u tom elitističkom krugu nije imao šta da traži, osim nekolicine pojedinaca koji su u svojstvu državnih agenata kreirali svjetsku politiku i pravdu. ${ }^{2}$

Pitanje - da li je pojedinac i kada postao subjekt međunarodnog prava - posmatramo iz dva ugla. Primo, krug subjekata bilo kog prava samostalno je određen tim pravom, nezavisno od drugih. Posjedovati subjektivitet $u$ unutrašnjem pravu nije i ne može biti argument za subjektivitet u međunarodnom i obratno. Subjektivitet je uvijek vezan za konkretni pravni poredak. Verzilj (Verzijl) je to slikovito opisao riječima: "Subjekti crkvenog prava ne mogu biti identični subjektima unutrašnjeg sekularnog privatnog prava. Kanonsko pravo prirodno prepoznaje različite 'subjekte' od onih koje priznaje luteranski crkveni red."3 Secundo, međunarodno pravo zahvaljujući svojoj autonomnoj prirodi samostalno određuje krug subjekata i to određenje vremenom može evoluirati. Kategorija subjektiviteta podložna je stalnim promjenama i nužno prati

\footnotetext{
${ }^{2} \mathrm{U}$ doktorskoj disertaciji posvećenoj ulozi pojedinca $\mathrm{u}$ kreiranju međunarodnog prava, odbranjenoj na britanskom univerzitetu Exeter 2014. godine, autor analizira aktivnosti pojedinačnih državnih agenata kao takvih, te govori o njihovoj ulozi u kreiranju prava. Više vidi u: Thomas Lesile Dunk, The Role of the Individual in the Process of International Law Creation, doktorska disetracija, University of Exeter, 2014, https://ore.exeter.ac.uk/repository/bitstream/handle/10871/ 16054/ DunkT.pdf?sequence=1\&isAllowed=y, 20/08/2020.

${ }^{3}$ Jan H. W. Verzijl, International law in hostorical perspective, part II, A. W. Sijthoff, Leiden, 1969, p. 4.
} 
konstantan razvoj međunarodnog prava. Subjekt u jednom vremenskom razdoblju nije nužno subjekt u nekom drugom. Brojni su primjeri entiteta koji su u jednom vremenskom razdoblju bili subjekti i samostalno stajali na svjetskoj sceni, no vremenom su ili izgubili status ili potpuno nestali. ${ }^{4}$

U periodu ranog razvoja međunarodnog prava, samostalnim subjektima su se smatrali pojedinci koji su upravljali određenim teritorijama, odnosno vladari država koje su učestvovale u kreiranju pravila. Moglo bi se reći da je u srednjem vijeku bilo manje kontroverzi oko tvrdnje da pojedinac jeste subjekt međunarodnog prava, nego danas. ${ }^{5}$ Nešto kasnije, nakon Vestfalskog mira i pobjede nacionalne države, subjektom su smatrane samo "prosvijećene države“. Nakon Prvog svjetskog rata dolazi do napuštanja elitističke koncepcije i krug subjekata se širi, da bi im se poslije Drugog svjetskog rata na pozornici pridružile i međunarodne organizacije. Danas, u mnogim oblastima savremenog međunarodnog prava, pojedinac stoji rame uz rame sa državama i međunarodnim organizacijama. Svako učestvuje u procesu na svoj način, u skladu sa sopstvenom prirodom. Verzilj u tom smislu zaključuje: "[O]čigledno je da međunarodno pravo može dodijeliti status subjekta pojedincu ukoliko se to smatra preporučljivim.."

Sasvim drugo pitanje je, međutim, da li je pravno utemeljeno i da li je preporučljivo pojedinca svrstati u krug subjekata međunarodnog prava. Promišljanja o položaju različitih nedržavnih aktera u okviru međunarodnog prava i njihova sistematizacija toliko su raznovrsni da ne bismo bili daleko od istine ukoliko bismo zaključili da podjela ima onoliko koliko i mudrih glava koje su o tome pisale. U zavisnosti od toga kako pojedini autori doživljavaju subjektivitet, kao statičnu ili dinamičnu kategoriju, čvrst standard ili rastegljiv pojam, kao suštinsko prethodno

\footnotetext{
${ }^{4}$ Vid. detaljnije Ibid., pp. 19-44.

${ }^{5} \mathrm{U}$ tom periodu, ugovore su zaključivali vladari međusobno. Tako npr. Ugovor o savezu iz 1387. godine "Alliance of 10 July 1387 between Richard III of England and William of Jülich and Guelders, on one hand, and Charles VI of France and his uncle, the Duke of Burgundy"... ili Ugovor o trgovini iz 1486. godine "Treaty of Commerce of 22 July 1486 between Henry VII of England and Duke Francis of Brittany", Ibid., pp. 18-19.

${ }^{6}$ Ibid., p. 6.
} 
pitanje ili naknadnu potvrdu, možemo da prepoznamo i njihovo razumijevanje položaja pojedinca. Za one autore koji subjektivitet smatraju osnovnom kategorijom, uslovljenom nekolicinom elemenata koji treba da su zastupljeni kumulativno, za njih je jedini subjekt država. Za one druge pak, koji subjektivitet vide kao dinamičnu kategoriju koja nužno prati stalan razvoj međunarodnog prava, subjektivitet zapravo i nije neophodno svojstvo, kada se u obzir uzimaju učesnici u procesima koji su brojni.

Budući da je naš zadatak da analiziramo razvojni put shvatanja o položaju koji pojedinac kao jedinka zauzima u doktrini međunarodnog prava, opredijelili smo se za bazičnu podjelu teoretičara na liniji odnosa pojedinca i države. Autore dijelimo u tri osnovne kategorije: pisci prema kojima je država jedini subjekt međunarodnog prava, a pojedinac prema tome objekt, pisci prema kojima su i države i pojedinci subjekti međunarodnog prava, i konačno pisci prema kojima je pojedinac isključivi subjekt. Svjesni smo rizika koji sa sobom nosi bazična kategorizacija, i spremni smo na kritiku u pogledu stavova pojedinih autora koji nisu eksplicitno iznijeli opredjeljenje prema bilo kojoj od grupa, a mi smo ih ipak u jednu od njih svrstali.

\section{SHVATANJA O ISKLJUČIVOM SUBJEKTIVITETU DRŽAVE}

Nebrojeno puta je u literaturi ponovljeno da su države jedini izvorni subjekti međunarodnog prava, da je ideja postala gotovo opšteprihvaćena i bez dodatne potkrepe. ${ }^{7}$ Tvrdnje o monopolu država

\footnotetext{
${ }^{7}$ Izdvojićemo neke od najuticajnijih autora koji zagovaraju ideju isključivog državnog subjektiviteta. Poći ćemo od Tripela koji je na Haškoj akademiji predmet međunarodnog prava odredio na sljedeći način: "Le droit international public règle des rapports entre des États et seulement entre des États parfaitement égaux. Les relations entre un État fédéral et ses États membres ne sont point du domaine du droit international parce que les États-membres sont soumis à l'État fédéral, et les relationsentre les individus et les États étrangers, ainsi que les relations entre des individus appartenant à différents États, ne sont point du régime du droit international public, parce que les individus nesont pas, comme on aime à dire, des «sujets » du droit international". Heinrich Triepel, "Les rapports entre le droit interne et le droit international", Recueil des cours de l'A cadémie de Droit International de la Haye 1/1923, 73-121, p. 81; Lassa Oppenheim,
} 
na međunarodnom nebu najčešće su bazirane na argumentu da su države zapravo jedini adresati pravila međunarodnog prava, te da prema tome pojedinac ne ispunjava ni onaj minimalni standard kad se radi o subjektivitetu. ${ }^{8}$ Drugi argument na koji nailazimo tiče se predmeta regulisanja međunarodnog prava. Prema njemu, međunarodno pravo, proisteklo iz prava naroda, proizvod je volje civilizovanih država koje su, stoga, jedini njegovi subjekti. ${ }^{9} \mathrm{U}$ interpretaciji koju nalazimo kod Portmana (Portmann), jedan od osnovnih postulata pomenutih teorija baziran je na činjenici da entitet koji nije učestvovao u kreaciji pravnih pravila međunarodnog prava, ne bi mogao ni biti vezan njima. ${ }^{10}$ Ovdje se zapravo radi o usvajanju dualističke teze o inherentnoj podvojenosti prava, na unutrašnje i međunarodno kojâ, iako se u nekim aspektima dodiruju, ne mogu nikada doći u koliziju, i primjeni ove teze na odnos između države i pojedinca. Iako je pojedinac direktni subjekt unutrašnjeg, državnog prava, koje se na njega direktno primjenjuje, isto se ne može reći i za međunarodno pravo. Jedini relevantan izvor pravne obaveze počiva na volji država, a varijacije su dozvoljene samo u pogledu načina na koji je ta volja izražena. ${ }^{11}$

Pisci poput Tripela (Triepel), Openhajma (Oppenheim) i drugih, adresatima prava i obaveza smatraju samo države i time, kako Politis (Politis) rezonuje, poistovjećuju „intristic value of these rules with their application ${ }^{\prime 12}$ Činjenica da su države potpisnici nekog međunarodnog

International law: A Treatise, 8th ed., Longmans, Geen and Co., London, 1955, p. 117 i dalje; David Feldman, "International personality", Recueils des cours 191/1985, pp. 343-414, 364 i dalje.

${ }^{8}$ Hans Aufricht, "Personality in international law", International Legal Personality (ed. F. Johns), Ashgate, England 2010, p. 49.

${ }^{9}$ Lassa Oppenheim, International law: A treatise, Vol I - Peace, 2nd ed., Longmans, Green and Co, London 1912, p. 107.

${ }^{10}$ Roland Portmann, Legal Personality in International Law, Cambridge University Press, Cambridge 2010, p. 47.

${ }^{11}$ Vidi više u: Ibid., pp. 59-64.

${ }^{12}$ Nikolaos Politis, "The new aspects of international law: A Series of Lectures delivered at Columbia University in July 1926", Carnegie Endowment for international peace, Washington 1928, p. 21. 
ugovora ne isključuje mogućnost da se norme sadržane u tom ugovoru tiču pojedinca direktno.

Prema onome što se u literaturi naziva tradicionalna pozitivistička doktrina, čini se vrlo jednostavno i jedino logično zaključiti da su samo države subjekti međunarodnog prava. Ta ideja se posmatra gotovo dogmatski, i činjenica da su se međunarodno pravo ali i okolnosti na međunarodnoj sceni promijenili tokom prošlog vijeka ne doprinosi značajano evoluciji shvatanja o pojedincu. Openhajmovo mišljenje dijeli većina pozitivista savremenog doba, iako su posebno poslije Drugog svjetskog rata pitanja poput položaja izbjeglica, apatrida ili međunarodnih službenika kao jedinki odvojenih od država dobila sasvim drugu dimenziju. „Budući da pravo naroda počiva na zajedničkoj volji (common consent) pojedinačnih država, a ne ljudskih bića, države su jedini $i$ isključivi subjekti međunarodnog prava. To znači da pravo naroda uređuje ponašanje država na međunarodnoj sceni, a ne njihovih građana. " ${ }^{13}$

Temelj ovog učenja, koje zapravo i nije jedna jedinstvena škola mišljenja već skup različitih struja koje polaze od iste ideje, baziran je na načinu na koje pravila međunarodnog prava nastaju. „Pravo je proizvod pravno relevantne volje $i$ (...) na međunarodnom planu države na bazi svog pristanka (consent) stvaraju medunarodno pravo koje ih obavezuje međusobno." 14 Dakle, u krajnjoj konsekvenci je teorija volje, odnosno zajednička volja država (common will of states) koja je osnov obaveznosti pravila međunarodnog prava. „Države su vezane [pravilima međunarodnog prava - op. a.] zato što, i samo dok, žele da budu vezane. Čak i obavezujuća snaga pravila pacta sunt servanda ne proizlazi ni iz čega drugog do zajedničke volje država (collective will of the states)." ${ }^{15}$

Teorije prema kojima je država jedini subjekt međunarodnog prava uglavnom, mada ne i uvijek, implicitno pojedinca određuju kao objekta

${ }^{13}$ Lassa Oppenheim (1912), International law: A treatise, Vol I - Peace, op. cit., p. 19, par 13.

${ }^{14}$ Peter Pavel Remec, The position of the individual in international law according to Grotius and Vattel, Martinus Nijhoff, The Hague 1960, p. 18.

${ }^{15}$ Dionisio Anzilotti, Corso di diritto internazionale, (3rd ed; Roma: Athenaeum, 1928), nav. prema: Ibid., p. 20. 
tog prava. Za Švarzenberga (Schwarzenberger), pojedinac je očigledni objekt međunarodnog prava, iako i sam priznaje da ne postoji objektivan razlog ili smetnja zbog koje pojedincu ne bi mogao biti dodijeljen subjektivitet. Poseban akcenat je upravo na riječi dodijeljen, budući da ona upućuje na način na koji autor razumije pojam subjektiviteta u međunarodnom pravu. Priznanje je, prema shvatanju koje zastupa ovaj eminentni pravnik, bitan element subjektiviteta i otuda se govori o dodjeljivanju subjektiviteta pojedincu. Dakle, države kao izvorni subjekti međunarodnog prava, mogle bi ukoliko bi željele uvrstiti i pojedinca u krug subjekata međunarodnog prava. Opšte pravilo koje bi spriječilo takvu pojavu ne postoji. Međutim, ovaj autor smatra da uprkos postojanju pravila iz oblasti međunarodne zaštite ljudskih prava, usmjerenih na pojedinca, to i dalje ne znači da je pojedinac subjekt. Sve dok je međunarodna zajednica decentralizovana zajednica suverenih i nezavisnih država, pojedinac prema ovom autoru ne može biti ništa drugo do objekt tog prava. Samo ukoliko bi se međunarodna zajednica transformisala u svojevrsnu svjetsku državu, pojedinac bi mogao postati subjekt.

"Ne postoji inherentna nemogućnost dodjeljivanja medunarodnog subjektiviteta pojedincima. Međutim, ne može se reći da su do sada države ovu osnovnu jedinicu unutrašnjeg i međunarodnog prava tretirale bilo šta drugo osim objekt međunarodnog prava. (...) Slično tome, ne čini se vjerovatnim da međunarodna zaštita ljudskih prava i osnovnih sloboda, kako je predviđena Poveljom Ujedinjenih nacija, utiče na osnovni položaj pojedinca kao objekta međunarodnog prava. Takva fundamentalna promjena kao što je transformacija pojedinca u subjekta nadnacionalnog prava pretpostavlja pretvaranje postojećeg svjetskog društva u federalnu svjetsku državu. ${ }^{" 16}$

Ono što je naročito sporno u ovom stavu je činjenica da se pojedincu odriče mogućnost međunarodnopravnog subjektiviteta na bazi argumenata koji kad se izvedu do kraja ukazuju na postojanje različitih pravnih poredaka. Naime, Švarzenberger smatra da bi pojedinac mogao biti subjekt međunarodnog prava samo ukoliko bi međunarodna

${ }^{16}$ Georg Schwarzenberger, A Manual of International Law, Stevens \& Sons Limited, London, 1947, p. 35. 
zajednica prerasla u svjetsku federaciju. Međutim, tada ne bismo mogli govoriti o međunarodnom već o unutrašnjem pravu, budući da je federacija prema unutrašnjoj strukturi oblik složene države koja, iako je in foro interno sastavljena od dvije ili više federalnih jedinica, ipak predstavlja jednu jedinstvenu državu in foro externo. Pojedinac bi u tom slučaju bio subjekt unutrašnjeg prava jedne velike svjetske države. A to nije poenta međunarodnog subjektiviteta. U svakom slučaju, pojedinac posjeduje subjektivitet $u$ unutrašnjim porecima različitih zemalja. Iz navedenog proizlazi da bi pojedinac mogao biti subjekt međunarodnog prava samo ukoliko međunarodnog prava ne bi ni bilo jer bi preraslo $u$ neko unutrašnje pravo nove svjetske države.

Znatno snažnije argumente u prilog tezi da pojedinac nije subjekt međunarodnog prava nalazimo $\mathrm{u}$ domaćoj literaturi, posebno $\mathrm{u}$ radu čuvenog pravnika Bartoša. Iako ovaj pisac ne spori da u međunarodnom pravu toga doba države nesumnjivo jesu dodijelile pojedincu važnu ulogu na međunarodnom planu, u vidu pravila o zaštiti prava čovjeka usvojenih nakon Drugog svjetskog rata, potom pravila o odgovornosti pojedinca za izvršenje zločina, kao i izolovanih slučajeva samostalnog istupanja pojedinca na međunarodnom planu, to ipak nije dovoljno da se izvede zaključak o samostalnom subjektivitetu pojedinca. Prava koja $\mathrm{su} \mathrm{u}$ međunarodnom poretku dodijeljena pojedincu "ne pripadaju neposredno njemu, već opštem pravnom poretku, a on se koristi tim poretkom. ${ }^{\text {17 }}$ Bartoš stoga zaključuje da "čoveka možemo smatrati samo refleksnim subjektom međunarodnog prava, tj. subjektom kome prava ne pripadaju neposredno, već se on koristi opštim međunarodnopravnim poretkom. "18 To ne znači da pojedinac u perspektivi ne bi mogao biti „učinjen“ subjektom međunarodnog prava, ali je pedesetih godina prošlog vijeka bilo nerealno o tome misliti imajući u vidu pravila o suverenitetu države te zabrani miješanja u unutrašnja pitanja pojedinih država. ${ }^{19}$ Pitanje je kako bi Bartoš ocijenio položaj pojedinca u današnjim uslovima.

\footnotetext{
${ }^{17}$ Milan Bartoš, Međunarodno javno pravo, I knjiga, Kultura, Beograd, 1954, str. 374. 18 Ibid.

${ }^{19}$ Ibid., str. 375.
} 
Tiunov (Tiunov) dolazi do istog zaključka, ali ga izvodi iz drugačijih argumenata. Naime, ovaj autor smatra da iako svaki subjekt međunarodnog prava jeste nužno adresat nekih prava i obaveza $u$ međunarodnom pravu, ipak se ne može reći i suprotno. Nije svaki adresat prava i obaveza subjekt međunarodnog prava. Odnosno, svojstvo adresata ili titulara prava i obaveza u međunarodnom pravu nije dovoljan uslov za posjedovanje subjektiviteta. Prema ovom autoru, potrebni su i drugi elementi.

„Neposredna inkorporacija pojedinaca u medunarodnu zajednicu ne daje im sposobnost stvaranja normi međunarodnog prava, njihovog proglašenja ili preuzimanja odgovornosti za njihovo kršenje. To su i dalje zadaci države. Iz tog razloga, pojedinci koji posjeduju prava u međunarodnom poretku ne mogu postati subjektima međunarodnog prava. Svaki subjekt $u$ međunarodnom pravu posjeduje medunarodna prava, ali nije svako ko posjeduje ta prava subjekt međunarodnog prava. ${ }^{20}$

Među savremenim piscima koji, uprkos sve snažnijim zalaganjima znatnog broja autora današnjice za individualizacijom ili, kako se to često naziva, humanizacijom međunarodnog prava, ipak odolijevaju pred izazovima i ostaju dosljedni tradicionalnoj ideji međunarodnog prava je i Hafner (Hafner). Na kursu održanom 2011. godine na Haškoj akademiji, naslovljenom „Emancipacija pojedinca od države u međunarodnom pravu“, ovaj pisac zaključuje da se ipak radi o procesu čiji su dometi ograničeni, budući da „položaj [pojedinca u međunarodnom pravu - op. a.] zavisi od izričite saglasnosti država ili, u slučaju multilateralnih sporazuma, saglasnosti date $u$ dodatnoj formi ili u formi posebnog sporazuma. Stoga, i dalje zavisi od volje države u svakom pojedinačnom slučaju da li će prihvatiti takve procedure." 21

Autor, potom, u istom maniru nastavlja: „Shodno tome, ne može se torditi da su pojedinci subjekti međunarodnog prava jer taj status zavisi od određenog pravnog poretka: u nekim regionalnim ili subregionalnim oblastima oni su priznati kao subjekti relevantnog pravnog poretka... Ali čak ni u ovom najrazvijenijem

${ }^{20}$ Oleg I. Tiunov, “The international legal personality of states: problems and solutions", Saint Louis University Law Journal, 37/1993, p. 335.

${ }^{21}$ Gerhard Hafner, "The Emancipation of the Individual from the State under International Law", Recueils des cours 358/2011, pp. 437-438. 
sistemu, pojedinci nemaju nikakve pravne instrumente za pokretanje postupka protiv država. Na univerzalnom nivou rijetko imaju pristup procedurama sprovođenja (enforce procedures), tako da ostaju u statusu objekata." ${ }^{22}$

Ovaj autor, dakle, vrlo bojažljivo prihvata konstantan razvoj pravila međunarodnog prava i promjene koje se dešavaju gotovo svakodnevno $\mathrm{u}$ decentralizovanoj međunarodnoj zajednici. Ostaje na sigurnoj putanji isključivog državnog subjektiviteta, uz jasnu naklonost izraženu ka afirmaciji položaja pojedinca.

\section{RAZVOJNI PUT IDEJE OD SUBJEKTIVITETA DRŽAVE DO SUBJEKTIVITETA POJEDINCA}

Pravni pisci koji su stvarali i djela koja su nastala u vrijeme klasičnog međunarodnog prava, dakle do početka Prvog svjetskog rata, međunarodno pravo predominantno vezuju za državu. Međutim, ne i isključivo. Znatan je broj teoretičara koji ulogu pojedinca $u$ međunarodnom poretku posmatraju kroz prizmu pravila koja se na njih primjenjuju direktno, bez posredstva države.

Vestlejk (Westlake), u djelu koje je svjetlost dana ugledalo daleke 1894. godine, izuzetno dopušta mogućnost subjektiviteta pojedinca, svakako u okviru pravila međunarodnog prava nastalih između država. „Bilo bi sitničavo piratima ili blokaderima [trgovački brod koji je služio za prevoz dobara u blokirani grad - op. a.] odreći subjektivitet u međunarodnom pravu, ali oni su to samo na osnovu pravila koja preovladavaju izmedu država." ${ }^{23}$ Značaj ove njegove ideje je daleko veći nego što se isprva čini. Naravno da se nije moglo govoriti o opštem subjektivitetu pojedinca $u$ međunarodnom pravu koje je bilo rudimentarno i nerazvijeno, i kome su nedostajala brojna pravila usmjerena ka pojedincu, a koja postoje danas. Konačno, ni sve države $\mathrm{u}$ tom periodu nisu bile subjekti međunarodnog prava. Ono što je značajno je ideja i način na koji su autoriteti u oblasti, poput ovog eminentnog pisca, rezonovali. On kaže

\footnotetext{
${ }^{22}$ Ibid., p. 441.

${ }^{23}$ Lassa Oppenheim, The Collected Papers of John Westlake on Public International Law, Cambridge Univeristy Press, Cambridge, 1914, p. 2.
} 
da se ne može piratu odreći subjektivitet $u$ domenu pravila koja se odnose na njega. Prevedeno u današnje okolnosti, pojedincu se ne može odreći subjektivitet u domenu pravila koja su mu upućena. I to je sasvim dovoljno ukoliko imamo na umu da subjektivitet u svakom slučaju nije statična kategorija, niti je kvalitet subjektiviteta isti za sve jedinke koje učestvuju u međunarodnim procesima.

Na drugom mjestu, ovaj autor iznosi sljedeću tvrdnju: „Budući da sve obaveze naposlijetku pripadaju čovjeku, ljudi koji sačinjavaju novu državu bili su vezani tim pravom kao članovi prethodne države, i ne mogu jednostranim aktom promijeniti osnovu na kojoj su njihovi odnosi sa drugim članovima međunarodnog društva zasnovani. ${ }^{24}$ Ovdje se govori o obavezama koje pogađaju novonastalu državu. Argumentaciju za to nalazi u činjenici da su obaveze, bez obzira na to što su formalno upućene državi, u krajnjoj mjeri zapravo obaveze pojedinca. Nastankom nove države, koju nastanjuju pojedinci koji su nastanjivali prethodnu državu, njih prate iste obaveze. Znači, ovaj autor potkrepljenje tvrdnje o obavezi novonastalih država da poštuju postojeća pravila međunarodnog prava bazira na činjenici da su suštinski sva ta pravila usmjerena ka pojedincu, u ma kojoj državi se on formalno nalazio.

Zarad akademske korektnosti, dužni smo istaći i to da u literaturi pronalazimo i drugačije tumačenje Vestlejkovih ideja o položaju pojedinca u međunarodnom pravu. Naime, naš autor Milojević, a prema navodima preuzetim od Korovica (Korowicz), Vestjelka svrstava u kategoriju onih pisaca koji pojedinca smatraju jedinim subjektom međunarodnog prava. Nismo sasvim sigurni šta je našeg pisca opredijelilo da u svojoj sistematizaciji teorijskih shvatanja o pojedincu Vestlejka svrsta među one pisce za koje je subjektivitet u međunarodnom pravu isključivo vezan za pojedinca, tim prije što ni Korovic na čiji rad Milojević upućuje tako ne čini. ${ }^{25} \mathrm{U}$ njegovom radu, kao i kod nas, Vestlejk je, istina bez neke opširne argumentacije, ipak svrstan u kategoriju pisaca za koje subjektivitet posjeduju i pojedinci i države, naravno, svako u

${ }^{24}$ Ibid., p. 82.

${ }^{25}$ Vidi: Momir Milojević, Položaj pojedinca i njegov aktivni subjektivitet u međunarodnom pravu, Jugoslovenski zavod za produktivnost rada, Beograd, 1987, str. 224-225. 
svom kapacitetu. Ovaj nerijedak fenomen u pravnoj literaturi, samo potvrđuje našu prethodno navedenu opasku o teškoćama adekvatne sistematizacije pojedinih autora ili njihovih zasebnih djela.

Ima svakako i onih pisaca koji su u svojim radovima jasno istakli opredjeljenje prema datoj temi, te lutanja u tom slučaju nisu moguća. Tako, na primjer, kod Kaufmana (Kaufmann) pronalazimo shvatanje prema kom se međunarodno pravo primjenjivalo na „pojedinačne države $i$ eventualno na pojedince $i$ državne organe, budući da su oni obuhvaćeni međunarodnom zajednicom naroda". ${ }^{26}$ Ovaj pisac, prema Politisovom viđenju "vrlo energično pokazuje da je stara doktrina prestala da bude tačna: pored odnosa između država, odsada postoji i međunarodni život pojedinca; međunarodno pravo ne reguliše samo prava $i$ dužnosti država, već reguliše $i$ prava $i$ dužnosti građana pojedinačnih država, u odnosima jednih sa drugima ili sa državama“. ${ }^{27}$

Le Fir (Le Fur), kako Kreća pažljivo zapaža, zadržava „uravnotežen $i$ realističan odnos prema pitanju subjektiviteta pojedinca" ${ }^{28}$ Prema ovom autoru, države su "najvažnija lica u međunarodnom pravu“ ${ }^{29}$ ali ne i jedina. Naime, u dijelu rada koji se tiče "ličnosti“ u međunarodnom pravu, ovaj autor posebno mjesto daje pojedincu. Vrlo pažljivo konstatuje da uprkos znatnom broju pravila međunarodnog prava koja se direktno odnose na pojedinca, on u pravilu nije neposredni adresat normi, te se načelno izvodi zaključak da se „u međunarodnom pravu, pojedinac (...) javlja na neki način kao prikriven državom". 30

Upor. Marek Korowicz, "The problem of the international personalityof individual", The American Journal of International Law 50/1956, str. 535.

${ }^{26}$ Wilh Kaufmann, Die Rechtskraft des internationalen Rechtes und das Verhältnis der Staatengesetzebung und der Staatsorgane zu derselben, F. Enke, Stuttgart, 1899, p. 77; nav. prema: Anne Peters, Beyond human rights: The Legal Status of the Individual in International Law, Cambridge University Press, Cambridge, 2016, pp. 16-17.

${ }^{27}$ Nikolaos Politis, "The new aspects of international law: A Series of Lectures delivered at Columbia University in July 1926", op. cit., p. 20.

${ }^{28}$ Luj Le Fir, Međunarodno javno pravo, Pravni fakultet Univerziteta u Beogradu, Beograd, 2010, p. 12.

${ }^{29}$ Ibid., p. 70.

${ }^{30}$ Ibid., pp. 113-114. 
Zanimljivo je i originalno Kelzenovo (Kelsen) poimanje položaja pojedinca $u$ okviru opšteg međunarodnog prava. U jednom dijelu njegovih radova čini nam se da ovaj autor zagovara isključivi subjektivitet pojedinca, dok u drugom vidimo da prihvata mogućnost subjektiviteta i država i pojedinaca. Tako, u svom čuvenom djelu „Opšta teorija prava $i$ države", ovaj autor iznosi shvatanje koje u krajnjim konsekvencama podržava ideju koju smo pronašli u učenju francuskih pisaca škole realizma. "Svekoliko pravo reguliše ljudsko ponašanje. Jedina društvena stvarnost na koju pravne norme mogu da se odnose su odnosi između ljudskih bića. Stoga, pravna obaveza kao i pravo ne mogu sadržati ništa osim ponašanja pojedinaca. Ako međunarodno pravo ne bi trebalo da obavezuje ili ovlašćuje pojedince, obaveze i prava stipulisana međunarodnim pravom ne bi imali nikakav sadržaj i međunarodno pravo ne bi moglo obavezati ili ovlastiti bilo koga da učini bilo šta." ${ }^{\text {"31 }}$

Iz prethodnih redova moglo bi se lako zaključiti da ovaj pisac subjektivitet $u$ međunarodnom, kao i unutrašnjem pravu, svodi na pojedinca, kao krajnjeg adresata norme. To, međutim, ne bi u potpunosti odgovaralo istini. Naime, u kasnijem Kelzenovom djelu „Principi međunarodnog prava“, pronalazimo nešto ublaženiju varijantu prethodno citiranog stava. Kelzen na ovom mjestu ne spori subjektivitet države $u$ međunarodnom pravu, ali iznosi opravdanje subjektiviteta pojedinaca. Dakle, najbliži istini je zaključak da su prema ovom eminentnom piscu subjekti međunarodnog prava i države i pojedinci. Sljedeći redovi upućuju na taj zaključak: „Subjekti međunarodnog prava su, takođe, pojedinci. Tvrdnja da su subjekti međunarodnog prava države kao pravna lica ne znači da subjekti međunarodnog prava nisu pojedinci; to znači da su pojedinci subjekti na poseban način, drugačiji od uobičajenog načina na koji su pojedinci subjekti unutrašnjeg prava. ${ }^{\text {"32 }}$

Kelzenov najbolji đak na Bečkom univerzitetu, prema njegovim sopstvenim riječima, bio je, kako se poslije ispostavilo, eminentni britanski

${ }^{31}$ Hans Kelsen, General theory of law and state, Harvard University Press, Cambridge Massachusetts, 1949, p. 342. Vid. Roland Portmann, Legal Personality in International Law, op. cit., p. 174.

${ }^{32}$ Hans Kelsen, Principles of International Law, second ed., Holt, Rinehart and Winston, Inc, New York, 1966, p. 180. 
pravnik i teoretičar, porijeklom iz Istočne Evrope, Herš Lauterpaht (Lauterpacht). ${ }^{33}$ Naslonjen na Kelzenovu pravnu epistemologiju, uprkos značajnim razlikama $u$ pristupu, Lauterpaht je u poslijeratnom periodu dao snažan doprinos afirmaciji „individualisticke koncepcije“ međunarodnog subjektiviteta. ${ }^{34}$

Lauterpaht je vjerovatno jedan od najčuvenijih pisaca $X X$ vijeka koji su otvoreno zagovarali ideju subjektiviteta pojedinca u međunarodnom pravu. Ovaj autor, suštinu svog elaborata o ulozi pojedinca u međunarodnom pravu $^{35}$ temelji na činjenici da u pozitivnom međunarodnom pravu nema pravila koje definitivno isključuje pojedince i druge nedržavne entitete iz kruga subjekata tog prava. ${ }^{36}$ Potrebno je u svakom pojedinačnom slučaju, bilo da se radi o pojedincu ili organizaciji, u obzir uzeti realitet i trenutno stanje u međunarodnom pravu. Mjerodavna je zapravo volja i namjera država, koju treba ispitati u svakom pojedinačnom slučaju. ${ }^{37}$

Njegova teorija predstavlja sintezu dotadašnjih teorijskih promišljanja na temu subjektiviteta pojedinca, koju je oblikovao $\mathrm{u}$ jedinstven teorijski okvir utemeljen prije svega na činjenici da u opštem međunarodnom pravu ne postoji pravilo koje prekludira pojedinca $u$ sticanju prava i dužnosti u međunarodnom poretku. Nadalje, to znači da pojedinac kao „ultimate unit“ posjeduje kvalitete svojstvene subjektu međunarodnog prava.

U radu koji, po sopstvenim riječima ovog autora, predstavlja njegovo najbolje djelo ikada napisano, ${ }^{38}$ objavljenom 1946. godine, Lauterpaht,

${ }^{33}$ Hans Kelzen, "Tributes to Sir Hersch Lauterpacht", European Journal of International Law 8/1997, p. 309, izvorno objavljen u časopisu International $\mathcal{E}$ Comparative Law Quarterly 1961. godine.

${ }^{34}$ Sintagma „individualistička koncepcija“ preuzeta je od Portmana. Vid. više u: Roland Portmann, Legal Personality in International Law, op. cit., str. 126 i dalje.

${ }^{35}$ Precizna formulacija koju autor koristi je pravo naroda (law of nations), vid. Hersch Lauterpacht, International Law and Human Rights, Stevens \& Sons Limited, London 1950, p. 3.

${ }^{36}$ Ibid., p. 4.

${ }^{37}$ Ibid., p. 61.

${ }^{38}$ Elihu Lauterpacht, The life of Sir Hersch Lauterpacht, Cambridge University Press, Cambridge 2010, pp. 279-280. 
pružajući iscrpnu analizu Grocijusovog doprinosa međunarodnom pravu, iznosi ono što čini nam se predstavlja suštinu njegovog razumijevanja položaja pojedinca u međunarodnom pravu. „Pojedinac je krajnja jedinica (the ultimate unit) svekolikog prava, medunarodnog $i$ unutrašnjeg, u dvostrukom smislu tako da su obaveze medunarodnog prava u krajnjoj konsekvenci njemu upućene $i$ da su razvoj, blagostanje $i$ dignitet ljudskog bića stvar direktne brige medunarodnog prava." ${ }^{39}$

Nakon usvajanja Povelje Ujedinjenih nacija postalo je jasno da pojedinac posjeduje prava $\mathrm{u}$ međunarodnom poretku, nezavisno od poretka država članica te organizacije. „U konstantom potvrđivanju 'osnovnih ljudskih prava' pojedinca nužno se mora smatrati da se ona odnose na prava priznata međunarodnim pravom i nezavisno od prava država. ${ }^{" 40} \mathrm{Na}$ bazi te činjenice, uz konstataciju da direktna zaštita pravâ nije nužno u korelaciji sa njihovim posjedovanjem, dok istovremeno sadrži eksplicitnu obavezu država članica da poštuju ta prava, ovaj autor zaključuje da već sama Povelja Ujedinjenih nacija kao akt od suštinskog značaja priznaje pojedince kao subjekte međunarodnog prava. ${ }^{41}$

„Interpretacija Povelje [Ujedinjenih nacija - op. a.] u tom smislu zavisi u značajnoj mjeri od shvatanja da ne postoji pravilo međunarodnog prava koje definitiono onemogućava pojedince i nedržavne entitete da stiču direktna prava ili dužnosti u okviru običajnog ili ugovornog medunarodnog prava, $i$ da su događaji iz posljednje četortine vijeka preveli taj kapacitet, u mnogim poljima u pogledu i prava i dužnosti, $u$ dio pozitionog prava." ${ }^{2}$

Dok je $\mathrm{u}$ teoriji bilo malo rasprave o direktnim pravima pojedinca $\mathrm{u}$ međunarodnom pravu, dotle je rasprava vođena o mogućnosti nametanja direktnih dužnosti normom međunarodnog prava. Distinkcija između države i pojedinca $u$ pogledu sposobnosti posjedovanja prava i dužnosti u međunarodnom poretku, prema

\footnotetext{
${ }^{39}$ Hersch Lauterpacht, ",The Grotian Tradition in International Law", British Year Book of International Law 1/1946, p. 27.

${ }^{40}$ Ibid., p. 34.

${ }^{41}$ Ibid., p. 35.

${ }^{42}$ Hersch Lauterpacht, International Law and Human Rights, Stevens \& Sons Limited, London, 1950, p. 4.
} 
Lauterpahtu, značila bi primjenu dvostrukih aršina i uvođenje nižih standarda za ovu potonju kategoriju. ${ }^{43}$ Odreći pojedincu svojstvo subjekta međunarodnog prava, na bazi činjenice da sopstvenim aktima ne može obezbijediti poštovanje tih prava, predstavlja zamjenu teza. Svojstvo titulara nekog prava garantovanog međunarodnim ugovorom ne treba poistovjećivati sa procesnom sposobnošću. „Pitanje da li su pojedinci subjekti medunarodnog prava u bilo kom slučaju $i$ da li ta osobina podrazumijeva $i$ sposobnost sprovođenja mora biti odgovoreno pragmatično imajući u vidu datu situaciju i odgovarajući međunarodni instrument. Taj instrument ih može učiniti subjektima prava a da im ne dodijeli procesnu sposobnost...". ${ }^{44}$ Ovaj pisac se, zapravo smatra, zaslužnim za afirmaciju dvije najvažnije novine u poslijeratnom međunarodnom pravu: pitanju ljudskih prava i individualne odgovornosti pojedinca u okviru opšteg međunarodnog prava. ${ }^{45}$

Ukazujući na teorije Digija i Scela, Lauterpaht polazi od istih premisa. Prije svega, država je sačinjena od jedinki, pojedinačnih ljudskih bića. I u pogledu odgovornosti, ukoliko se ne bi mogla pripisati čovjeku od krvi i mesa ostala bi bespredmetna ${ }^{46} \mathrm{~A}$ činjenica da pojedinac nema punu procesnu sposobnost $\mathrm{u}$ međunarodnom pravu ne predstavlja potpunu negaciju njegovog subjektiviteta, već samo umanjuje kvalitet subjektiviteta koji pojedinac u međunarodnom pravu posjeduje. ${ }^{47} \mathrm{Za}$ ovog autora, teorija koju zastupaju etatisti, o isključivom subjektivitetu država i prema tome pojedincu kao objektu međunarodnog prava lišena je suštine, a bazirana je na pogrešnom uvjerenju da je država kao kolektivno biće potpuno odvojena od lica koja je čine. ${ }^{48}$

Na istoj liniji rezonovanja nalazi se i britanski pravnik i teoretičar međunarodnog prava druge generacije, Elihu Lauterpaht, koji kao

\footnotetext{
${ }^{43}$ Ibid., p. 5.

${ }^{44}$ Ibid., p. 27.

${ }^{45}$ Janne Elisabeth Nijman, The Concept of International Legal Personality: An inquiry into the history and theory of international law, T. M. C. Asser Press, Leiden 2004, p. 300.

${ }^{46}$ Ibid., p. 40.

${ }^{47}$ Ibid, p. 61.

${ }^{48}$ Ibid, p. 70.
} 
argument $\mathrm{u}$ prilog tezi iznijetoj na prethodnim stranicama, $\mathrm{o}$ podijeljenom subjektivitetu država i pojedinaca, ističe činjenicu da etatistička teza nije bila u potpunosti prihvaćena ni u XIX vijeku, kada je doživjela svoj procvat, te tim prije ne može biti bespogovorno prihvaćena ni vijek kasnije, $u$ vremenu kada i pojedinci i međunarodne organizacije posjeduju širok spektar prava i dužnosti u međunarodnom pravu. ${ }^{49}$

\section{TEORIJSKA SHVATANJA O ISKLJUČIVOM SUBJEKTIVITETU POJEDINCA}

U dijelu teorije koji zagovara koncepciju prema kojoj je pojedinac isključivi subjekt međunarodnog prava, subjektivitet se posmatra kao svojstvo, a priori koncept, koji ne zavisi od volje država i stoga ne može biti njome ograničen. Budući da se radi o zbiru raznovrsnih teorija naslonjenih na prirodnopravna, sociološka pa i psihološka učenja, sistematizaciju izabranih autora smo napravili s obzirom na period u kom su stvarali svoja djela, počevši od perioda poslije Prvog svjetskog rata, odnosno vremena konstituisanja univerzalnog međunarodnog prava.

Teorija između dva svjetska rata

Na osnovu činjenice da je država pravna apstrakcija i da su krajnji korisnici prava ili nosioci obaveza uvijek pojedinci, mnogi autori dolaze do zaključka da jedini pravi subjekt međunarodnog prava jeste pojedinac. Već u periodu između dva svjetska rata, u naučnim krugovima Evrope postavilo se pitanje subjektiviteta u međunarodnom pravu i entiteta koji se mogu podvesti pod taj genusni pojam. Razloge za pojačanu individualizaciju u teoriji međunarodnog prava treba tražiti $\mathrm{u}$ društvenopolitičkim zbivanjima nakon I svjetskog rata, propasti Društva naroda kao svojevrsnog političkog projekta i potrebi uspostavljanja pravednijeg globalnog društva zaštićenog od rastućeg

${ }^{49}$ Elihu Lauterpacht, "The development of the law of international organization by the decisions of international tribunals", Recueils des cours 152/1976, p. 403. 
totalitarizma. ${ }^{50}$ Godina 1926. bila je u tom smislu plodna za mnoge evropske teoretičare. Vodeći pisci toga doba su se u različitim evropskim i svjetskim pravnim krugovima bavili pitanjem subjektiviteta pojedinca.

Tako je ostalo zabilježeno da je pomenute godine Njemačko udruženje za međunarodno pravo (DeutschenGesellschaftfürVöllkerrecht) organizovalo diskusiju na temu subjekata međunarodnog prava. Za to vrijeme vrlo inovativno, postavljeno je pitanje eventualnog subjektiviteta pojedinca u međunarodnom pravu. „Ko se može samostalno pojaviti pred međunarodnim forumima? Samo države? Ili i ostali, konkretno pojedinci? (...) U 19. vijeku tim problemom se gotovo niko nije bavio." ${ }^{51}$

I danas se na ideju o subjektivitetu pojedinca $u$ jednom dijelu akademskih i naučnih krugova gleda kao na kuriozitet i futurističku zamisao, tako da možemo pretpostaviti kakav odjek je pomenuti skup izazvao u naučnoj i stručnoj javnosti tadašnje Evrope. Zaključci koji su tom prilikom usvojeni pokazuju ne naročito rigidne stavove vodećih njemačkih teoretičara, koji na temelju činjenice da manjine ili pojedinci postaju korisnici prava i obaveza u međunarodnom pravu, posebno kroz podnošenje zahtjeva za naknadu štete pretrpljene u Prvom svjetskom ratu, uviđaju sve prisutniju transformaciju „deep conceptual substructure (Grundauffassung) of international law", prema kojoj su države bile isključivi subjekti međunarodnog prava. Ipak, da bi se došlo do preciznog odgovora na postavljeno pitanje neophodno je izvršiti dublju analizu međunarodnih ugovora, pravnih tekstova, kao i prakse. ${ }^{52}$

Gotovo istovremeno, i u Austriji se preispituje dogma o državnom subjektivitetu. Verdros (Verdross) zauzima stav prema kome je ideja o

${ }^{50}$ Anne Peters, Beyond human rights: The Legal Status of the Individual in International Law, op. cit., p. 20. Upor. Janne Elisabeth Nijmann, The Concept of International Legal Personality: An inquiry into the history and theory of international law, op. cit., pp. 86-87.

${ }^{51}$ Godehard J. Ebers, "Sind im Völkerrecht allein die Staaten parteifähig?", Mittelungen der Deutschen Gesellschaft für Völlkerrecht 7/1926, str. 7, nav. prema: Natasha Wheatley, "Spectral Legal Personality in Interwar International Law: On New Ways of Not Being a State", Law and History Review, 35/2017, p. 754 fn. 3.

52 Tekst usvojenih zaključaka vid. u: Rolf Knubben, Die Subjekte des Völlkerrechts: allgemeine Lehre von der vollen und beschränkten völlkerrechtlichen Rechts - und Handlungsfähigkeit, Kohlhammer, Stuttgart 1928, vorwort. 
državi kao jedinom subjektu međunarodnog prava postala mit, i opisuje ga sljedećim riječima: „Ipak, tek nedavno je magija ove jeresi počela da nestaje. ${ }^{\text {53 }}$ Međutim, dalje od toga ne bismo mogli ići, iako smo u literaturi nailazili na različita tumačenja Verdrosovog poimanja međunarodnog prava i subjekata tog poretka. ${ }^{54}$ Naime, $\mathrm{u}$ radu objavljenom nakon Drugog svjetskog rata, i u vrijeme kada čovječanstvo i međunarodna zajednica stupaju u novu eru, ovaj autor pojedince opisuje kao pasivne subjekte, koji iako su direktni adresati normi međunarodnog prava, ipak ne mogu učestvovati u njihovom stvaranju. ${ }^{55}$

U sličnom maniru, o pitanju subjektiviteta elaborira i grčki pravnik i političar Politis koji u predavanju održanom na Kolumbija (Columbia) univerzitetu 1926. godine znatnu pažnju posvećuje upravo tom pitanju. Osvrnuvši se na temeljnu koncepciju pozitivističkog učenja baziranog na teoriji volje, ovaj autor kritikuje pristup prema kome je država jedini subjekt međunarodnog prava. Ide i korak dalje, te konstatuje kako je ideja o državnom subjektivitetu postala beskorisna. ${ }^{56}$ Zajednička volja države, na kojoj je, kako smo već pisali, Tripel utemeljio svoje učenje, za Politisa je "lična volja određenih pojedinaca koji su uspjeli pridobiti ostale jedinke da učestouju u njoj. (...) Subjektivitet države je samo metafora koja omogućava ljudima da razlikuju akte Vlade od njihovih privatnih akata. ${ }^{157}$

${ }^{53}$ Alfred Verdross, Die Verfassung der Volkerrechtsgemeinschaft (Vienna and Berlin:Verlag von Julius Springer, 1926), p. 116; nav. prema: Natasha Wheatley, "Spectral Legal Personality in Interwar International Law: On New Ways of Not Being a State", op. cit., p. 755.

${ }^{54}$ Konkretno, ruski teoretičar i sudija Ustavnog suda Ruske Federacije, Tiunov, u radu na koji smo već upućivali, kao potkrepljnje vodećeg stava sovjetske teorije o isključivom državnom suverenitetu navodi i tezu pomenutog zapadnoevropskog pisca Verdrosa o nepostojanju subjektiviteta pojedinca, koju mi, istina $\mathrm{u}$ ograničenom broju Verdrosovih radova koji su nam bili dostupni, ipak nismo mogli pronaći. Vid. Oleg I. Tiunov, "The international legal personality of states: problems and solutions", op. cit., p. 334.

${ }^{55}$ Alfred Verdross, "On the concept of International law", The American Journal of International law 43/1949, p. 439.

${ }^{56}$ Nikolaos Politis, "The new aspects of international law: A Series of Lectures delivered at Columbia University in July 1926", op. cit., p. 13.

${ }^{57}$ Ibid., pp. 13-14. 
Kad govori o klasičnom međunarodnom pravu, Politis primjećuje da je „kao i teritorija, on [pojedinac - op. a.] mogao biti samo objekt međunarodnog prava ${ }^{\prime \prime}{ }^{58}$ Međutim, XX vijek donio je očigledne promjene u međunarodne odnose, na koje ni teorije o subjektivitetu nisu mogle ostati imune. Politis, stoga, zaključuje: „Postalo je nemoguće održati ideju da, nezavisno od svoje države, pojedinac, pravno posmatrano, nema ulogu u međunarodnim odnosima. (...) Nema razloga zašto, u drugim okolnostima [osim u slučaju lica bez državljanstva, ili kako ih ovaj autor naziva "Heimatlosen" - op. a.] mogućnost direktne primjene medunarodnog prava na pojedince kao takve ne bi mogla biti prihvaćena. Pozitivno pravo to priznaje u velikom broju slučajeva, koji će postati sve brojniji kako se aktivnosti pojedinca na međunarodnom planu budu

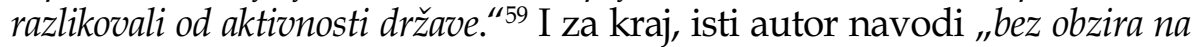
socijalni milje u kom se primjenjuje, pravo uvijek ima istu osnovu, budući da mu je objekt uvijek isti: bavi se čovjekom i samo čovjekom" ${ }^{60}$

Radi dodatnog potkrepljenja svojih stavova, Politis navodi čitavu plejadu pisaca koji su zagovarali ideju subjektiviteta pojedinca. Inter alia, gore pomenuti autor ukazuje na Heftera (Heffter) koji posmatra čovjeka kao jedinku koja, per se, posjeduje međunarodna prava i obaveze nezavisno od države čije državljanstvo posjeduje. ${ }^{61}$ Čak ide i korak dalje pa konstatuje da pojedinac ne samo da je subjekt međunarodnog prava, već i član međunarodne zajednice. ${ }^{62} \mathrm{U}$ godinama koje su uslijedile, mnogi autori iz vodećih evropskih zemalja, na bazi Hefterove vizije izgradili su, uz manje ili veće modifikacije, sopstveno stanovište o ulozi pojedinca $\mathrm{u}$ međunarodnom poretku.

Linija rezonovanja, koju uz pomoć socioloških objašnjenja iznosi Politis, ide otprilike ovako: ljudi kao jedinke se grupišu u grupe, klanove, potom gradove i konačno države. Za sve to vrijeme pojedinac je i dalje prisutan, ne gubi svoje svojstvo time što je član neke više zajednice. ${ }^{63}$

\footnotetext{
${ }^{58}$ Ibid., p. 18.

${ }^{59}$ Nikolaos Politis, "The new aspects of international law: A Series of Lectures delivered at Columbia University in July 1926", op. cit., pp. 20-21.

${ }^{60}$ Ibid., p. 26.

${ }^{61}$ Ibid., p. 19.

62 Ibid.

${ }^{63}$ Ibid., pp. 23-24.
} 
Država, kao jedan od najviših oblika zajednice jedinki zapravo je samo pravna apstrakcija, odnosno sistem veza među ljudima koji čine njeno stanovništvo. ${ }^{64}$ Stoga, jedino razumno je zaključiti da kao krajnji adresat svih pravnih normi, pojedinac zapravo jeste jedini i isključivi subjekt međunarodnog prava.

\section{Teorija poslije Drugog svjetskog rata}

Poslije Drugog svjetskog rata predviđanja mnogih autora dobila su svoj normativni okvir. Američko udruženje za međunarodno pravo je već 1941. godine raspravljalo o subjektivitetu u kontekstu trenutnih društvenih okolnosti. Jedan od govornika, na tada održanoj konferenciji, Dun (Dunn) ideju o međunarodnom pravu kao pravu koje uređuje odnose između država u kojima nema mjesta za pojedinca nazvao je „pravnim fosilom [koji] je krajnje varljiv i u velikoj mjeri pogrešan, i njegovo konstantno zadržavanje u mislima mnogih ljudi djelimično objašnjava zašto međunarodno pravo ima tako lošu reputaciju među laicima danas. "65 Isti autor dalje konstatuje da koncept isključivog državnog subjektiviteta zapravo samo odražava teorijske stavove, a ne i stvarne postupke država. ${ }^{66}$

Svoj inspirativni govor dalje nastavlja riječima: „Davanje subjektiviteta državi, a ne pojedincu je možda bezopasni dio antropomorfizma u normalnim vremenima, ali u sadašnjoj krizi postoji velika opasnost da će biti pogrešno shvaćen. Time se predlaže hladna nezainteresovanost prema interesima $i$ dobrobiti čovjeka na ulici i pogodan je da u njemu probudi jednako ravnodušnost prema statusu međunarodnog prava. Za službenika, ozbiljno preuveličava važnost političkih odnosa država na račun aktionosti ljudi kao ljudskih bića" ${ }^{67}$

Ma koliko povoljno sa aspekta humanizacije međunarodnog poretka kao univerzalnog zaštitnika čovjeka zvučale prethodno navedene riječi pomenutog autora, ipak je uočljivo da u njima ima vrlo malo

\footnotetext{
${ }^{64}$ Ibid., p. 25.

${ }^{65}$ Frederick S. Dunn, “The International Rights of Individuals”, American Society of International Law Proceedings vol. 35, Second Session, 1941, p. 14.

${ }^{66}$ Ibid.

${ }^{67}$ Ibid., pp. 16-17.
} 
normativnog i realnog $\mathrm{u}$ vremenskom okviru u kom su iznijete. Ovi stavovi imaju vrijednost prije svega kao pokazatelj stremljenja istaknutog teoretičara i njegovog opredjeljenja prema pitanju subjektiviteta pojedinca, a nikako kao pokazatelj praktičnog položaja koji pojedinac zaista zauzima u međunarodnom pravu generalno. Ipak, naveli smo ih kao pokazatelja opšte tendencije u poslijeratnoj pravnoj teoriji.

U francuskoj poslijeratnoj teoriji, u okviru tzv. škole realizma (école réaliste) koja predstavlja manjinu u tadašnjim naučnim krugovima, ${ }^{68}$ posebno je značajno shvatanje čuvenog teoretičara Sela (Scelle) koji smatra, prije svega, da je sam termin subjekt prava nejasan, „,... sujets de droit ...étant équivoque ${ }^{\prime \prime}{ }^{69}$ Potom, navodi i da je ideja o isključivom subjektivitetu države naučno nedokazana, ,aprioristicka, nedopustiva i bezobzirna, kao sama ličnost države. To je u suprotnosti sa bilo kakvom realnom koncepcijom međunarodnog društva. ${ }^{70}$ Komentarišući stav Stalnog suda međunarodne pravde $\mathrm{u}$ predmetu o nadležnosti sudova $\mathrm{u}$ Dancigu, ovaj autor primjećuje da Sud ide i mnogo dalje i priznaje međunarodnopravnu ličnost pojedinca kao nužno izvedenu iz njegovih kapaciteta u okviru međunarodnog poretka, bez obzira na volju država u tom konkretnom slučaju. ${ }^{71}$ Svaki građanin, bez obzira na pripadnost državi, istovremeno pripada i međunarodnom poretku, zaključuje Sel. ${ }^{72}$

Prethodno napisane redove svakako treba uzeti sa određenom dozom rezerve. Posmatrati državu isključivo kao „pravnu mašineriju za regulisanje prava i dužnosti pojedinaca ${ }^{\prime 73}$ predstavlja vulgarizaciju centralnog koncepta zahvaljujući kome međunarodno pravo kao takvo i postoji na prvom mjestu. Ukoliko državu svedemo na mašineriju potpuno podređenu

${ }^{68}$ Nicolas Leroux, "Non-state actors in French legal scholarship", Praticipants in the International Legal System: multiple perspectives on non-state actors in international law (ed. J. D'Aspremont), Routledge, London-New York 2011, p. 85.

${ }^{69}$ Georges Scelle, Cours de Droit International Public, Editios Domat Montchrestien, Paris 1948, p. 507.

${ }^{70}$ Ibid., p. 510.

${ }^{71}$ Ibid.

${ }^{72}$ Ibid. p. 512.

${ }^{73}$ Humphrey Waldock, "General Course on Public International Law", Recueil des cours 106/1962, p. 192. 
pojedincu, prema Voldoku (Waldock), dovodimo u pitanje i pravo kao "artificial system". ${ }^{74}$

Prva polovina XXI obilježena je u znatnoj mjeri povratkom na osnove prirodnog prava predstavljene $u$ djelima tzv. očeva međunarodnog prava. Revizija stavova o položaju pojedinca u međunarodnom pravu nametnula se kao jedan od obaveznih koraka $\mathrm{u}$ tom procesu. $\mathrm{Za}$ holandsku autorku Nijman, na čije stavove smo ukazivali na više mjesta $\mathrm{u}$ ovom radu, pojedinac je subjekt par excellence međunarodnog prava. ${ }^{75}$ "Pojedinac je i izvor i krajnji adresat prava naroda. ${ }^{\text {76 }}$

Pored pomenute autorke, potrebno je ukazati i na stavove jednog od najglasnijih pobornika humanizacije međunarodnog prava našeg doba, sudije Međunarodnog suda pravde, Kandade-Trindadea (Cançado Trindade) koji u opširnoj analizi iz 2012. godine, koju možemo uzeti kao referentnu kada se radi o njegovim stavovima u pogledu pravnog položaja pojedinca u međunarodnom pravu, vrlo jasno iznosi ideju o pojedincu kao nesumnjivom subjektu kako unutrašnjeg tako i međunarodnog prava. ${ }^{77}$ Izražavajući oštru kritiku prema tradicionalnom shvatanju subjektiviteta, te zahtjevu za ispunjenošću svih elemenata tog pojma svojstvenih državi, ovaj autor ukazuje na činjenicu da, primjera radi, ni u unutrašnjem pravu svi pojedinci ne učestvuju direktno $u$ procesima stvaranja prava, ali im nije osporen subjektivitet. ${ }^{78}$ "Taj trend $u$ doktrini, insistirajući na tako rigidnoj definiciji međunarodnog subjektiviteta, uslovljavajući ga elementom stvaranja normi i postupanjem prema njima, jednostavno nije održiv, čak ni na nivou unutrašnjeg prava, u kom nije ni neophodan - niti je ikada bio... ${ }^{\text {"79 }}$ Pojedinac je, za ovog autora, subjekt iure

74 Ibid.

${ }^{75}$ Janne Elisabeth Nijman, The Concept of International Legal Personality: An inquiry into the history and theory of international law op. cit., p. 473.

${ }^{76}$ Ibid.

77 Antonio Augusto Cançado Trindade, "The historical Recovery of the Human Person as Subject of the Law of Nations", Cambridge Journal of International and Comparative Law 1/2012, p. 15.

${ }^{78}$ Ibid. p. 16.

${ }^{79}$ Ibid., pp. 16-17. 
suo međunarodnog prava. ${ }^{80}$ Svjestan da je pristup teoriji međunarodnog prava, koji već decenijama njeguje i elokventno iznosi kroz naučne radove ili praksu sudova (autor je ranije bio sudija Interameričkog suda za ljudska prava), u najmanju ruku nekonvencionalan i u pogledu ideja originalan, ovaj autor prilikom svog obraćanja studentima u Kembridžu (Cambridge) 2012. godine, priznaje ono što se vrlo lako izvodi kao zaključak nakon analize njegovih djela - vođen idealima, a ne postojećim pravilima, pažnju usmjerava na vrijednosti i pravo kakvo treba da bude da bi se najviši ciljevi mogli postići.

\section{ZAKLJUČAK}

Iako je nesumnjivo utvrđeno da određenje pojma međunarodnopravnog subjektiviteta, kao jednog od fundamentalnih pitanja međunarodnog javnog prava, proističe iz shvatanja o državi i njenom položaju u međunarodnom poretku, ipak je jasno da su ideje o isključivom državnom subjektivitetu danas pravno neodržive. Ne samo u kontekstu savremene međunarodne zajednice, već od vremena ranog razvoja pravila međunarodnog prava, prihvaćena je i u teoriji prepoznata izuzetna uloga pojedinca u funkcionisanju postojećeg pravnog poretka izvan granica državnih jurisdikcija. Takozvana humanizacija međunarodnog pravnog poretka zapravo nije nikakva revolucionarna novina XXI vijeka, već prosta recepcija ideja iznijetih neposredno po okončanju Prvog svjetskog rata.

Ovaj rad posvetili smo istraživanju doktrinarnih stavova o ulozi pojedinca i njegovom odnosu prema državi kao tradicionalno jedinom originernom subjektu međunarodnog prava. Pružajući temeljan pregled postojećih teorijskih sazanja o subjektivitetu pojedinca u međunarodnom pravu, a posebno vodeći računa o izvornoj ideji svakog od autora koji su bili predmet naše naučne obrade, od najranijieg vremena do danas, nastojali smo doprinijeti boljem razumijevanju razvojnog puta koncepta međunarodnopravnog subjektiviteta pojedinca. Analizom iznijetih stavova odabranih pisaca, ukazali smo na činjenicu da mnoštvo teorijskih

${ }^{80}$ Ibid., p. 19. 
pravaca o ovom pitanju ne podrazumijeva nužno i nepremostive razlike među njima. Poseban izazov bio je sistematizovati pravne pisce $u$ odgovarajuće, iako nikada do kraja utvrđene, teorijske pravce, budući da je, kako smo u radu vidjeli, za znatan broj njih usljed proteka vremena, promjene društveno-političkih zbivanja i naprosto razvoja pravila međunarodnog prava došlo do evolucije same ideje o pravnom položaju pojedinca u jednom tako dinamičnom pravnom poretku. Očigledno je, stoga, da se na pitanje ko su subjekti međunarodnog prava, odnosno kakav je pravni položaj nedržavnih aktera u međunarodnom pravu, nikada ne može dati konačan odgovor. Odgovor na ovo pitanje će uvijek zavisiti od vremena u kom se za njim traga.

Naše opredjeljenje prema trenutnom položaju pojedinca $u$ međunarodnom pravu i njegovom mogućem razvoju pro futuro, potvrđeno nakon pregleda osnovnih teorijskih stavova, najbolje odražavaju sljedeće Portmanove riječi: „Dakle, u međunarodnom pravnom sistemu ne postoji ništa što sprečava pojedince da postanu stalni subjekti međunarodnog prava, sve zavisi od toga koje su adresate međunarodne norme propisale u datom trenutku u vremenu" ${ }^{81}$

${ }^{81}$ Roland Portmann, Legal Personality in International Law, op. cit., p. 176. 


\title{
EVOLUTION OF THE CONCEPT OF SUBJECTIVITY OF THE INDIVIDUAL IN INTERNATIONAL LAW
}

\begin{abstract}
In this paper, we start from the assumption that subjectivity is a dynamic concept, subject to changes that are conditioned by the continuous development of the rules of international law, which ultimately affects the understanding of the position of the individual in the coordinates of the mentioned system. Depending on how individual authors perceive subjectivity, as a static or dynamic category, a solid standard or a stretchable concept, an essential preliminary question or subsequent confirmation, we can also assess their understanding of the position of the individual. The idea that the individual is a subject of international law is not new, just as the current trend of humanization of the legal order is not new. Regardless of the writer's experience of subjectivity, it has been undoubtedly established that different entities can be understood as subjects of international law. The determination of the status of the individual in international law has changed with the change of understanding of the state and its role. For those authors who consider subjectivity as a basic category, conditioned by the elements that should be represented cumulatively in the being of one entity, the only subject is the state. For others, who see subjectivity as a posteriori legal construction, conditioned by the development of the rules of international law, subjectivity extends inter alia to the individual. We will show that the dilemmas, which occupied the classics of international law in terms of the eventual subjectivity of the individual, are equally relevant today. Our goal is to prove that in this particular case, it is more about the reception of old ideas and dressing them in a new guise than about the revolutionary new phenomena of today.
\end{abstract}

Keywords: individual, international legal subjectivity, state, non-state actors. 